\title{
Reproductive Biology of an Endangered Coldwater Fish Golden Mahseer, Tor Putitora (Ham.) From Anji Mahseer Hatchery Reasi (J\&K)
}

\author{
Shabana Arjamand ${ }^{1}$, Shabir Ahmad Dar $^{2}$, A. Y. Desai ${ }^{3}$, A.N. Sayani ${ }^{4}$, \\ S. I. Yusufzai ${ }^{5}$, Ashfaq $\mathrm{M}^{6}$, Bhola D.V ${ }^{7}$ and M.D. Fofandi ${ }^{8}$ \\ 1 ( Govt, Degree College, Boys Baramulla, Kashmir, India) \\ 234567 (College of Fisheries, JAU, Veraval, Gujarat, India.) \\ 8 (Central Marine Fisheries Research Institute, Karwar, Karnataka, India)
}

\begin{abstract}
The Golden Mahseer (Tor Putitora) forms an important fishery resource in coldwater areas of Himalaya, India. The study covers reproductive factors of T. putitora from Anji Mahseer Hatchery Reasi, Jammu \& Kashmir. Fecundity and Gonadosomatic Index (GSI) of T. putitora was calculated monthly for a period of six months from March' 2011 to August' 2011. The observations related to fecundity and GSI are based on six female specimens of T. putitora ranging from $260 \mathrm{~mm}$ to $550 \mathrm{~mm}$ in total fish length and weight ranging between 280 grams to 800 grams. The mean value of fecundity was estimated as 5566 eggs for a fish with a mean total body length of $395 \mathrm{~mm}$ and mean body weight of $455 \mathrm{gms}$. The value of GSI was found to increase from March onwards reaching a peak in June, July and August. The peak was maintained in June, July and august, the highest value for GSI was calculated as 10.812 in the month of August.
\end{abstract}

KEYWORDS: Golden mahseer, Fecundity, Gonadosomatic Index, Anji Mahseer Hatchery Reasi, Jammu and Kashmir.

\section{INTRODUCTION}

The Golden mahseer also known as yellow fin mahseer occurs all along the base of Himalayas including Kashmir, Pakistan and Bangladesh. The elegant group of sport fish is Mahseer considered as the tiger of water in peril. The population of this fish has been declining because of over fishing, habitat loss, introduction of exotic species and human modifications to the environment (Joshi, 1987). One of the aspects of the environmental degradation is the altered ecology and destruction of breeding and feeding grounds due to the river valley projects. In Kashmir valley mahseer was the major fish having a major socio- economic role. But in recent years it has come under threatened category of fish species and are now rare in catches with dangers posed by construction of series of dams, barrages $\&$ weirs across the river in one hand and over exploitation on the other hand. While unrestrained fishing and disparaging fishing devices had adversely affected the riverine population. However, the construction of dams acts as physical barriers to this migratory species, tending to prevent their access to their usual breeding and feeding grounds (Pathani,1979). The denunciation of migration also results permanent and irretrievable eradication of fish stock ranging from depletion to complete extermination. Further mahseer populations are also affected by morphological modifications resulting from completion of river valley projects. These include change in shape, river bed profile, submersion of gravel zones or riffle section as well as destruction of reparian vegetation $\&$ changes in tropic regimes. There are fish species living in different ecosystems of the state, which are severely threatened on account of altered weather pattern \& high degree of toxic pollutants filling the rivers of Jammu \& Kashmir like Tawi in Jammu \& Jhelum in Kashmir valley, which has ultimately dwindled their numbers and the livelihood of those who are dependent on their catches. Trout fishes of Kashmir like (Triplophysa kashmirensis) \& mahseer fish (T. putitora) of river Tawi Jammu are facing the biggest threat along with Ladakh loach ( $T$. landacensis).The absence of great mahseer $(T$. putitora) in Jhelum is due to presence of the Mangla dam further downstream in Pakistan. This barrage lacks a fish ladder and has thus cut the migration route of this anadromous fish which earlier had its spawning grounds in the Kashmir valley. (Nyman, 1995). The alarming trend of its decline forced the J\&K state fisheries department to establish an exclusive mahseer hatchery at Anji (Distt. Reasi), where successful breeding programme of this species being taken up since 1999.

\section{I.I Study area}

The study site was selected at Anji Mahseer Hatchery (Reasi) of Jammu \& Kashmir state. It is spread over an area of 36 kanals. It consists of a water filtration plant, hatchery unit, five large concrete rearing ponds \& a well equipped laboratory. Hatchery unit was established in 1995 by the then Director of Fisheries R.K 
Dogra. Source of water to Anji mahseer hatchery is from Anji stream which is an important tributary of river Chinab. The environmental conditions and water parameters for breeding of mahseer was reported to be conducive where high percentage of hatching success is achieved. It has now restocked mahseer fishes in streams and rivers of Jammu and even in river Jhelum Kashmir but unfortunately it could not survive in Jhelum but thrives well in Jammu. Mahseer thrives well in Anus, Anji, PoniTawi, Radh nallah etc in Jammu division with good news of success farm officials are thinking about adaptation of some intensive methodology and technical manpower relating to seed production and propagation of mahseer fish. Artificial breeding as well as propagation of mahseer is being carried out from Aug, 2011. The establishment of Anji Mahseer Hatchery is an essential effort of the State Fisheries Department for the conservation and rehabilitation of this group of fish. The facilities in the farm are limited and it needs more advanced hatchery practices and quality control measures to enhance the seed production for restocking our waters with mighty mahseer.

\section{Material and Methods}

Samples of T. putitora were collected from Anji mahseer hatchery monthly for a period of six months from March' 2011 to August' 2011 by using the pond collection net. In the field the fishes were preserved in ice box and brought to the laboratory for further investigations, where they were washed in running tap water to remove mucous and other extraneous matter before studying. The samples were analyzed for fecundity and gonadosomatic index (GSI).

\section{II.I Fecundity}

Fecundity is the estimation of ova content in the ovary of a matured female specimen. The fish was dissected with the help of sterile blade and was exposed. The undisturbed mass of ovary was taken out in intact form. It was accurately weighed. . Five different sections, each of $1000 \mathrm{mg}$ in weight was taken from the anterior, middle \& posterior regions of ovary. Sections were weighed on electronic weighing device. Ova from these five small sections of ovary were separated by teasing and counted. As it was over, the individual number of these sections was added and made a sum total of it. Then the fecundity of the collected specimen was calculated as mentioned below.

$$
\mathrm{F}=\frac{\mathrm{W} \times\left(\mathrm{n}_{1}+\mathrm{n}_{2}+\mathrm{n}_{3}+\mathrm{n}_{4}+\mathrm{n}_{5}\right)}{\left(\mathrm{W}_{1}+\mathrm{W}_{2}+\mathrm{W}_{3}+\mathrm{W}_{4}+{ }^{\mathrm{W}}{ }_{5}\right)}
$$

Where, $\mathrm{F}=$ Fecundity

$\mathrm{W}=$ Total weight $(\mathrm{g})$ of the ovary

$\mathrm{n}_{1}+\mathrm{n}_{2}+\mathrm{n}_{3}+\mathrm{n}_{4}+\mathrm{n}_{5}=$ No. of ova in five sub samples of the ovary.

$\mathrm{W}_{1}+\mathrm{W}_{2}+{ }^{\mathrm{W}_{3}}+{ }^{\mathrm{W}}{ }_{4}+{ }^{\mathrm{W}}{ }_{5}=$ weight of five sub samples of ovary in grams.

\section{II Gonadosomatic Index (GSI)}

A live ripe female specimen was collected. Its weight and total body length was accurately determined. It was dissected and finally the ripe ovaries were exposed and were taken out carefully in intact form. Weight of gonads was taken on the electronic weighing machine. Both the results were noted down. Ultimately GSI value of female specimen was calculated. GSI was calculated according to the Giese \& Pears (1974) to know the maturity and to determine the breeding cycle. This was done as percentage of the gonad weight $(\mathrm{GW})$ in terms of body weight (BW) of the fish.

$$
\text { GSI }=\frac{\text { Weight of gonads }}{\text { Weight of fish }} \times 100
$$

\section{RESULTS \& DISCUSSION}

\section{III.I Sexual Dimorphism:}

Secondary sexual characters in T. putitora are quite pronounced during the spawning season. The male and female fishes can be easily distinguished by their shape, size and body coloration. Normally the males are bright in colour with elongated bodies as compared to the females having deep \& dull coloured bodies with bright orange tinge on the anal fins. This differentiation is not always helpful to distinguish the sexes; however, it can be used with other diagnostic characters. The anal fin in the female fishes is opaque and shorter than pectoral fins. In the male fishes, the pectoral fins are rough and harder as compared to those in the females. Pathani (1978) observed that during breeding season a clear cut body streak starting from the tip of the snout \& extending up to opercular bone on both the sides of the head appears in males. Tubercles are rarely seen in the 
male fishes. However, In Present study period, most of the male specimen of fishes develops dark grey or black coloration on their bellies during the breeding season.

Eggs of T. putitora are orange yellow in colour and their size range between $2.0 \mathrm{~mm}$ and $3.2 \mathrm{~mm}$. Though the facilities are limited in the farm, about $70-80 \%$ of fertilization is achieved. Hatchlings appear after 73 to 90 hours at room temperature (22 to $28{ }^{\circ} \mathrm{C}$ ). Time of hatching of eggs depends on water temperature. Mahseer attains maturity at the age of two years. Females are stripped at the age of three years and males at the age of two. Mahapatra and Vinod (2005) reported that the age at first maturity in males of chocolate mahseer was $9+$ months while in female fishes it was $11+$ months.

\section{III.II Fecundity:}

Breeding season of T. putitora in Anji mahseer hatchery was between July, August and September. As this fish breed several times during a year, the period between mid August to mid September is its peak spawning season in a year. It was found that the number of eggs varied from 4026 (for a fish with total length of $260 \mathrm{~mm}$ and total weight of 280grams) to 7695 (for a fish with total length of $550 \mathrm{~mm}$ and total weight of 800 grams). The mean value of fecundity of T. putitora was estimated as 5566 eggs for a fish with a mean total body length of $395 \mathrm{~mm}$ and mean body weight of $455 \mathrm{grams}$. Pathani (1981) also reported that fecundity of $T$. putitora ranged between 7076-18525, in the size range 33.90-51.70 cm total fish length and it increased with the increase in size.

\section{III.III Gonadosomatic Index:}

Gonadosomatic Index is widely used by biologists to indicate the maturity and periodicity of spawning and predicting the breeding season of a fish. Total six specimens of $T$. putitora of size range between $260 \mathrm{~mm}$ $550 \mathrm{~mm}$ and weight ranged from $280-800 \mathrm{gm}$ were used to calculate the Gonadosomatic as shown in Table 1. It was found that the values of gonadosomatic Index increase from March onwards reaching a peak in June. The peak was maintained in June, July and August. Highest value of GSI was found in the month of August Which was 10.812, which indicates spawning season of the fish. Similar results were also shown by Alam \& Pathak (2010) in Labeo rohita that the value of GSI reached at the peak in the month of August, which indicated the spawning period of Labeo rohita. The mean value of fecundity of Labeo rohita collected from Ramganga River was estimated as $66823.70 \pm 4312.39$ eggs with a mean total length of $183.06 \pm 5.60 \mathrm{~mm}$ and total body weight of $315.64 \pm 16.59$ grams.

\section{ACKNOWLEDGEMENT}

I am thankful to M.H. Balkhi for the present study for funding to carry out this research work. I am also thankful to T.A. Qureshi for his valuable suggestion in this research paper.

\section{REFERENCES}

[1] M Alam, and J. K. Pathak, Assesment of Fecundity and Gonadosomatic Index of commercially important fish, Labeo rohita from Ramganga river, International Journal of Pharma and Bio Sciences 1 (3), 2010,111.

[2] S.D Bhat, and J. K. Pathak, Himalayan environment (Shree Almora book Depot, Almora, 1992).

[3] C.B Joshi, (1987): Aquaculture of Mahseer, Tor putitora. (Cold water Aquaculture and Fisheries, 1987)

[4] S.S Pathani, Fecundity of Mahseer Tor putitora (Ham. Proc. Indian Acad Sci. (Anim. Sci.), 90: 1981, 253-260.

[5] S.S Pathani, Studies on the spawning ecology of Kumaun Mahseer Tor tor (Hamilton) and Tor putitora (Hamilton). J. Bombay Nat. Hist. Soc. 79(3), 1982, 525-530.

[6] S.P Piska, and J.K Waghary, A note on fecundity of Amblypharyngodon mola (Ham). J. Indian Inst. Sci. 66: 1986, 85-88.

[7] B.K Mahapatra, and K Vinod, Reproductive biology and artificial propagation of chocolate mahseer Neolissocheilus hexagonolepis (Mc Clelland) in Meghalaya, India. Indian J. Fish; 58 (2), 2005, 35-40.

[8] G.S Sandhu, K.K Tandon, and M.S Johal, Maturity, Fecundity and Sex-Ratio of an endangered COLD WATER FISH, Golden Mahseer, Tor putitora (Ham) from Gobindsagar (H.P.), India. Cold water Aquaculture \& Fisheries, pages: 265-278, 1990.

[9] S.S De Silva, B Ingram, S Sungan, D Tinggi, G Gooley, and S. Y Sim, Artificial propagation of the indigenous Tor species, empurace (T. tam bridges) and semah (T. douronensis), Sarawak, East Malaysia. Research and Farming techniques, Vol. ix, no. 4, 2004,15-20. 
Table 1: Determination of no. of ripe ova in fresh matured female specimens (Fecundity) \& Gonadosomatic index (GSI) From March, 2011 to August, 2011.

\begin{tabular}{|c|c|c|c|c|c|}
\hline Month & $\begin{array}{c}\text { Length of } \\
\text { specimen }(\mathrm{mm})\end{array}$ & $\begin{array}{c}\text { Wt. of } \\
\text { specimen }(\mathrm{g})\end{array}$ & $\begin{array}{c}\text { Total weight } \\
\text { of ovary }(\mathrm{g})\end{array}$ & Fecundity & GSI \\
\hline March,2011 & $550 \mathrm{~mm}$ & 800 & 45 & 7645 & 5.625 \\
\hline April,2011 & $510 \mathrm{~mm}$ & 700 & 42 & 6905 & 6.143 \\
\hline May,2011 & $400 \mathrm{~mm}$ & 290 & 25 & 5621 & 8.612 \\
\hline June,2011 & $260 \mathrm{~mm}$ & 280 & 30 & 4026 & 10.714 \\
\hline July,2011 & $300 \mathrm{~mm}$ & 290 & 30 & 4342 & 10.344 \\
\hline August,2011 & $350 \mathrm{~mm}$ & 370 & 40 & 4812 & 10.812 \\
\hline
\end{tabular}

